\title{
Theoretical study of the possibility of L-tryptophan with thiotriazoline complex formation
}

\author{
L. I. Kucherenko ${ }^{1,2}$, I. A. Mazur ${ }^{1,2}$, S. A. Borsuk ${ }^{1}$, 0. V. Khromylova ${ }^{1}$, S. V. Shishkina ${ }^{2}$ \\ ${ }^{1}$ Zaporizhzhia State Medical University, Ukraine, ${ }^{2}$ SPA “Farmatron”, Zaporizhzhia, Ukraine
}

Key words:

L-tryptophan,

thiotriazoline,

quantum chemical

calculations,

energy of complex

formation,

combination drugs.

\section{Zaporozhye}

medical journal

2018; 20 (1), 110-115

DOl:

10.14739/2310-1210

2018.1.122127

E-mail:

borsuksergejjj@ gmail.com
Introduction. For the joint use of L-tryptophan with tiotriazoline, it is necessary to solve the problem of the possibility of formation of sufficiently stable intermolecular complexes of these compounds. Therefore, it seemed interesting to consider the possible structure and energetic characteristics of complexes formed by L-tryptophan, 3-methyl-1,2,4-triazolyl-5-thioacetate (MTTA) and morpholine to create a dosage form.

Purpose of the study. To investigate the structure and evaluate the energy formation of three-component complexes of L-tryptophan, 3-methyl-1,2,4-triazolyl-5-thioacetate and morpholine quantum chemistry methods have been used. This study allows to estimate the possibility of combining these substances into a single dosage form.

Materials and methods. Thiotriazoline and L-tryptophan were used as objects of the study. The initial approximation to the geometry of the complexes was obtained using the molecular docking technique using the AutoDock Vina program. At the first stage the docking was carried out for MTTA and morpholine, according to the results of which 50 most stable complexes were selected for the construction of three-component complexes. Further, docking of obtained complexes of MTA and morpholine with the L-tryptophan molecule was carried out, and also the 50 most stable complexes were selected. Thus, 2500 initial geometries were obtained for each of the three-component complexes.

Study results. Quantum-chemical calculations show that L-tryptophan and thiotriazoline are capable to form three-component complexes, the molecules in which are connected by a lot of intermolecular hydrogen bonds. Each of the molecules is linked by intermolecular hydrogen bonds to the other two in one complex only. All other complexes contain the components which are linked sequentially: morpholine - MTTA - tryptophan. The results of quantum-chemical calculations make it possible to assume that the studied complexes are thermodynamically unstable in an infinitely dilute solution. The formation energies of the complexes are positive, despite the presence of a lot of charge assisted intermolecular hydrogen bonds. This can be caused by the high conformational flexibility of the molecules in which the groups participating in the formation of hydrogen bonds are separated by bridge containing several methylene groups and a fairly easy transfer of protons participating in the formation of hydrogen bonds.

Conclusions. The results of quantum-chemical study of a system consisting of three components (L-tryptophan, MTTA and morpholine) showed that the most thermodynamically stable three-component complexes have a positive energy of formation in infinitely dilute solutions. Despite the possibility of the formation of intermolecular hydrogen bonds between the components, some of which are charge-assisted, the L-tryptophan, MTTA and morpholine system is a mixture of substances, which makes it possible to use it in a single dosage form.

\section{Ключові слова:}

L-триптофан,

тіотриазолін, квантово-хімічні розрахунки, енергія утворення комплексів, комбіновані препарати.

Запорізький медичний журнал. - 2018. T. 20, № 1(106). -

C. 110-115

\section{Теоретичне дослідження можиивості утворення комплексів L-триптофану з тіотриазоліном}

\section{А. І. Кучеренко, І. А. Мазур, С. О. Борсук, О. В. Хромильова, С. В. Шишкіна}

Для спільного застосування L-триптофрану з тіотриазоліном необхідно вирішити питання про можливість утворення доволі стійких міжмолекулярних комплексів цих сполук. Тому було цікаво розглянути можливу структуру та енергетичні характеристики комплексів, що утворені L-триптофаном, 3-метил-1,2,4-триазоліл-5-тіоацетатом (MTTA) і морфоліном, для створення лікарської форми.

Мета роботи - методами квантової хімії дослідити будову й оцінити енергію утворення трикомпонентних комплексів L-триптофану, 3-метил-1,2,4-триазоліл-5-тіоацетату та морфоліну та вивчити можливість поєднання цих речовин в одній лікарській фрормі.

Матеріали та методи. Об’єкт дослідження - тіотриазолін і L-триптофан. Початкове наближення до геометрії комплексів отримано за допомогою програми AutoDock Vina. Для побудови трикомпонентних комплексів на першому етапі проводився докінг МТТА та морфоліну, за результатами якого відібрали 50 найстабільніших комплексів. Надалі здійснили докінг комплексів MCTA, що отримали, та морфоліну з молекулою L-триптофрану, за результатами якого також відібрали 50 найстабільніших комплексів. Отже, для кожного з трикомпонентних комплексів одержали 2500 можливих варіантів геометрії.

Результати. Квантово-хімічні розрахунки показують, що L-триптофан і тіотриазолін здатні утворювати трикомпонентні комплекси, молекули в яких пов'язані завдяки багатьом водневим зв'язкам. Тільки в одному комплексі кожна з молекул пов'язана міжмолекулярними водневими зв'язками з двома іншими. Усі інші комплекси містять компоненти, що пов'язані послідовно: морфолін - МТТА - триптофан. Квантово-хімічні розрахунки дають змогу припустити: вивчені комплекси термодинамічно нестабільні в нескінченно розбавленому розчині. Енергії утворення комплексів позитивні, незважаючи на зарядове посилення ряду водневих зв'язків, що зумовлено високою конформаційною гнучкістю молекул.

Висновки. Квантово-хімічне дослідження системи, що складається з трьох компонентів (L-триптофан, MTTA та морфолін), показало: найбільш термодинамічно стабільні трикомпонентні комплекси мають позитивну енергію утворення в 
нескінченно розведених розчинах. Незважаючи на можливість утворення між компонентами водневих зв'язків, частина з яких є зарядово-посиленими, система L-триптофан - MTTA - морфолін являє собою скоріше суміш речовин, що дає можливість використовувати їх в одній лікарській формі.

\section{Теоретическое исследование возможности образования комплексов L-триптофана с тиотриазолином}

\section{А. И. Кучеренко, И. А. Мазур, С. А. Борсук, О. В. Хромылёва, С. В. Шишкина}

Для совместного применения L-триптофана с тиотриазолином необходимо решить вопрос о возможности образования достаточно устойчивых межмолекулярных комплексов этих соединений. Поэтому представлялось интересным рассмотреть возможную структуру и энергетические характеристики комплексов, образованных L-триптофраном, 3-метил-1,2,4-триазолил-5-тиоацетатом (МTTA) и морфолином, с целью создания лекарственной формы.

Цель работы - методами квантовой химии исследовать строение и оценить энергию образования трехкомпонентных комплексов L-триптофана, 3-метил-1,2,4-триазолил-5-тиоацетата и морфолина и изучить возможность использования данных веществ в одной лекарственной форме.

Материалы и методы. Объектом исследования являлись тиотриазолин и L-триптофан. Исходное приближение к геометрии комплексов получено с помощью программы AutoDock Vina. Для построения трехкомпонентных комплексов на первом этапе проводился докинг МТТА и морфолина, по результатам которого отобрано 50 наиболее стабильных комплексов. Далее проведен докинг полученных комплексов MCTA и морфолина с молекулой L-триптофана, по результатам которого также отобраны 50 наиболее стабильных комплексов. Таким образом, для каждого из трехкомпонентных комплексов получено 2500 возможных вариантов геометрии.

Результаты. Квантово-химические расчеты показывают, что L-триптофан и тиотриазолин способны образовывать трехкомпонентные комплексы, молекулы в которых связаны за счет множественных водородных связей. Только в одном комплексе каждая из молекул связана межмолекулярными водородными связями с двумя другими. Все остальные комплексы содержат компоненты, связанные последовательно: морфолин-МТТА-триптофан. Проведенные квантово-химические расчеты позволяют предположить, что изученные комплексы термодинамически нестабильны в бесконечно разбавленном растворе. Энергии образования комплексов положительные, несмотря на зарядовое усиление ряда межмолекулярных водородных связей, что обусловлено высокой конфрормационной гибкостью молекул.

Выводы. Проведенное квантово-химическое исследование системы, состоящей из трех компонентов (L-триптофан, MTTA и морфолин), показало, что самые термодинамически стабильные трехкомпонентные комплексы имеют положительную энергию образования в бесконечно разбавленных растворах. Несмотря на возможность образования между компонентами межмолекулярных водородных связей, часть из которых является зарядово-усиленными, система L-триптофан - MTTA - морфолин представляет собой скорее смесь веществ, что позволяет использовать их в одной лекарственной форме.

\section{Introduction}

In connection with the high prevalence of mental pathologies, the development of inadequate adaptive reactions in a large part of the population, the pathological response of the human body to stressful effects, and the further development of severe disadaptation of various mental and somatic pathologies in a large part of the population are one of the topical problems of modern clinical medicine. The reason for this is the development of not only mental disorders, such as depression, emotional stress, mnestic disorders, but also other pathologies that arise precisely as a result of stress. Examples include hypertension, coronary heart disease, bronchial asthma, hyperthyroidism, dermatosis, peptic ulcer and duodenal ulcer, functional irritable bowel syndrome, etc. [1]. Despite constant efforts to optimize the treatment of diseases of the central nervous system, the problem remains not fully resolved. An important element of solving this complex problem is the creation of new highly effective and safe drugs, the use of which would lead to a decrease in the prevalence of mental disorders and diseases, improvement of quality and longevity.

Consequently, the development of neuropsychotropic substances with anxiolytic, stress-protective, nootropic activity is an actual problem of pharmacy and medicine. In modern pharmacy and medicine, substances of the class of neurotransmitter amino acids are increasingly used. They regulate and correct the course of mental disorders in patients who have undergone stress, psychological stress by controlling the main functions of the body, including movement, emotional reactions and physical ability to feel pleasure and pain [2].

Arginines, glycine, GABA, taurine, tryptophan, lysine, glutamic acid, etc. are the most known neurotransmitter amino acids that affect mood regulation.

Currently, the creation of drug based on fixed combination of L-tryptophan with antioxidants is one of the promising approaches in the development of new drugs. Thiotriazoline is one of the striking examples of the domestic preparations of the group of antioxidants, which was developed by the employees of SPA «Farmatron», as well as by the specialists of the Department of Pharmaceutical Chemistry of the Zaporozhye State Medical University under the guidance of prof. Mazur I. A. This drug has antioxidant, membrane stabilizing, anti-ischemic, antiarrhythmic, immunomodulating, anti-inflammatory, hepatoprotective, cardioprotective effect. Therefore, it is of interest to create a new combinated drug in the form of tablets containing L-tryptophan (Fig. 1) and thiotriazoline (Fig. 2) [3]. For the joint use of L-tryptophan with thiotriazoline, it is necessary to solve the problem of the possibility of formation of sufficiently stable intermolecular complexes of these compounds. Therefore, it seemed interesting to
Кмючевые слова:

L-триптофан, тиотриазолин, квантовохимические расчеты, энергия образования комплексов, комбинированные препараты.

\section{Запорожский} медицинский журнал. - 2018. -

T. 20, № 1(106). C. 110-115 
consider the possible structure and energetic characteristics of complexes formed by L-tryptophan, 3-methyl-1,2,4-triazolyl-5-thioacetate (MTTA) and morpholine.

Objective: to investigate the structure and evaluate the formation energy of three-component complexes of L-tryptophan, 3-methyl-1,2,4-triazolyl-5-thioacetate and morpholine compounds using quantum-chemical methods and to study the possibility of combining of these substances into a single dosage form.

\section{Materials and methods}

Tiotriazoline (Fig. 1) and L-tryptophan (Fig. 2) were used in the studies.<smiles>NC(Cc1c[nH]c2ccccc12)C(=O)O</smiles>

Fig. 1. Structural formula of L-tryptophan.<smiles>Cc1nc(SCC(=O)[O-])n[nH]1</smiles>

Fig. 2. Structural formula of thiotriazoline.

The procedure which is similar to that used earlier in the study of thiotriazoline and isoniazide complexes was used to simulate the structure and stability of L-tryptophan and thiotriazoline complexes [4].

The initial approximation to the geometry of the complexes was obtained using the molecular docking technique within the AutoDock Vina program. At the first stage docking

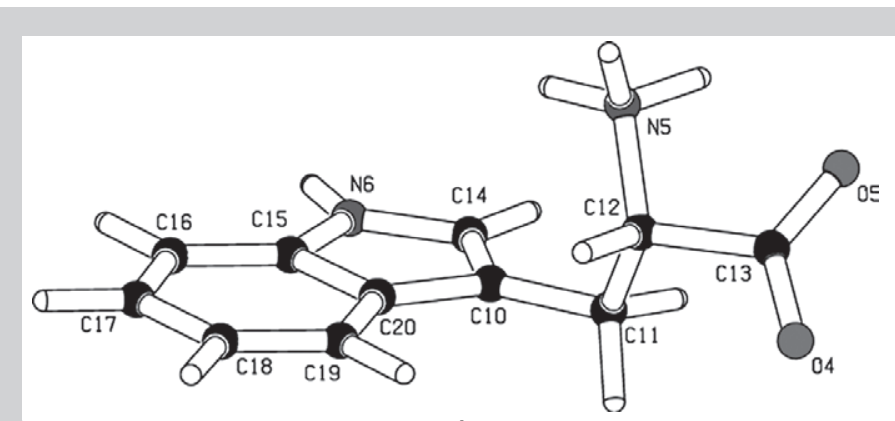

1

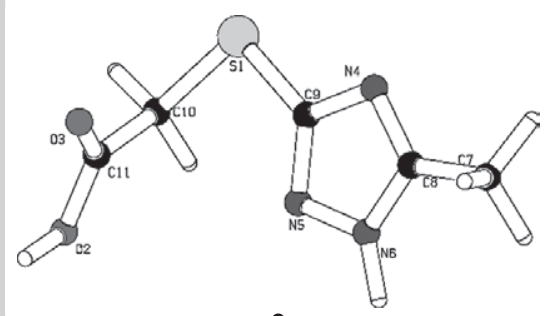

2

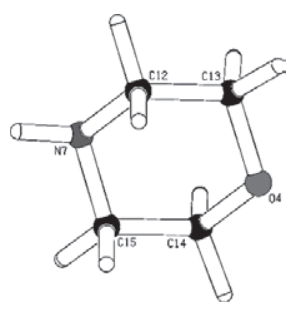

3

Fig. 3. The structure of isolated molecules of L-tryptophan (1), MTTA (2), morpholine (3) and their atomic numbering used in quantum chemical calculations. of MTTA and morpholine was carried out, according to the results of which 50 most stable three-component complexes were separated out. Further, docking of obtained complexes of MTA and morpholine with the L-tryptophan molecule was carried out, and also the 50 most stable complexes were selected. Thus, 2500 initial geometries were obtained for the three-component complexes. This procedure was carried out for each of the possible tautomeric forms of the three-component complexes [5].

At the second stage, the obtained three-component complexes were preliminarily optimized by the semi-empirical PM7 method with modeling of environment influence by COSMO method. The calculations were carried out using MOPAC2012 program [6]. Based on the results of calculations, 100 most stable structures were selected for each of the complexes, which were then optimized by the density functional method with B97-D3/SVP+COSMO (Water) empirical dispersion correction [7] using geometric correction for incompleteness of the gCP basic set [8]. 10 complexes with the lowest energy were selected from the obtained structures of the three-component complexes for which the final calculation of the geometry and thermodynamic parameters in the hard rotor approximation by the B97-D3/TZVP+COSMO method was carried out. A more accurate calculation of the energy of solvation was carried out by SMD method. Calculations by the density functional method were carried out using ORCA 3.0.3 program [9]. The formation energy of the complexes in solution was calculated as the difference between the free Gibbs energies of the solvated complex and its solvated individual components.

The chosen technique, which relies on the study of the complete conformational space of complexes by molecular docking methods and a series of sequential quantum chemical calculations using increasingly higher methods, guarantees with a high degree of probability the most stable three-component complexes.

\section{Results and discussion}

Previous studies of thiotriazoline [10] have shown that MTTA is easily deprotonated by converting to an organic anion, and morpholine, respectively, becomes a cation by attaching a hydrogen atom. Thus, the MTTA and morpholine compound is an organic salt. On the other hand, L-tryptophan, being an amino acid, must exist as a zwitterion (Fig. 1). In this case, the zwitterionic form of L-tryptophan acts simultaneously as both a proton donor and an proton acceptor in the formation of charge-assisted intermolecular hydrogen bonds with the morpholinium cation and the MTTA anion. This suggests the possibility of forming of both two-component complexes involving L-tryptophan and one of the components of thiotriazoline, and three-component complexes involving all three molecules. The multiplicity of donor and acceptor properties in all three molecules under study makes it possible to form a sufficiently large number of possible complexes.

The structure of isolated molecules and the atoms numbering are shown in Fig. 3.

Quantum-chemical calculations show that L-tryptophan and thiotriazoline are capable of forming of three-component complexes, the molecules in which are connected by 
multiple hydrogen bonds. From 4 to 5 intermolecular hydrogen bonds are formed in the most stable complexes. The structure of the most stable complexes with L-tryptophan with thiotriazoline and morpholine, their formation energies $(\mathrm{kcal} / \mathrm{mol})$ and hydrogen bond characteristics $(\mathrm{H}$...A, $\AA$ and $D-H . . . A$, deg.) obtained by the method of B97-D3/ TZVP+SMD (Water) are given in Table 1.

The analysis of the binding order of components in the 10 most stable three-component complexes (Fig. 4) showed some regularities. Only in complex 1 each of the molecules is linked by intermolecular hydrogen bonds with other two. All other complexes contain the components which are linked sequentially: morpholine-MTTA-tryptophan.

It should be noted that the protonated amino group and the deprotonated carboxyl group of tryptophan located at the same carbon atom form an intramolecular hydrogen bond in almost all cases. In the formation of intermolecular hydrogen bonds, the protonated amino group of amino acid is most active proton donor, providing from two (complexes 2, 6-10) to three (complexes 3 and 5 ) of hydrogen bonds with MTTA in 8 of 10 complexes. The morpholine molecule proved to be a much less active donor of the proton, in spite of the protonation of the nitrogen atom and the positive charge on it. Moreover, in complex 7, the morpholine molecule is not only a proton donor, but also a proton acceptor in hydrogen bonding. $\mathrm{NH}$ group of triazole ring shows proton donor properties only in complexes 3 and 7 . $\mathrm{NH}$ group of bicyclic amino acid fragment (complexes 3, 5, 6 and 8) also showed the properties of the proton donor in the intermolecular hydrogen-bonding.

In turn, deprotonated carboxyl group MTTA is the most active proton acceptor which is also involved in the formation of two simultaneous intermolecular hydrogen bonds in complexes 2, 3, 5, 6, 8-10. Deprotonated carboxyl group of amino acid forms an intermolecular hydrogen bond as a proton acceptor in only three out of ten complexes (complexes $1,3,7$ ). It can be assumed that this is caused by its involvement in the formation of an intramolecular hydrogen bond. The triazole MCTA cycle, despite the absence of a negative charge on it, also proved to be a sufficiently active proton acceptor. This MTTA fragment is involved in the formation of intermolecular hydrogen bonds in all ten complexes, and forms simultaneously two hydrogen bonds in complexes 4-6.

The results of quantum-chemical calculations make it possible to assume that studied complexes are thermodynamically unstable in an infinitely dilute solution. The formation energies of the complexes are positive, despite the charge-assisted character of a number of intermolecular hydrogen bonds.

Apparently, this is due to the high conformational flexibility of the molecules in which the groups participating in the formation of hydrogen bonds are separated by bridge containing several methylene groups and a fairly easy transfer of protons participating in the formation of hydrogen bonds.

It should be noted that the solvation energies were calculated in the approximation of infinite dilution. In solutions of a finite concentration, greater stability of molecular complexes should be expected due to the enhancement of intermolecular interactions.

Table 1. The structure of the most stable complexes with L-tryptophan with thiotriazoline and morpholine, their formation energies $(\mathrm{kcal} / \mathrm{mol})$ and hydrogen bond characteristics (H...A, $\AA$ and D-H...A, deg.) obtained by the method of B97-D3/TZVP+SMD (Water)
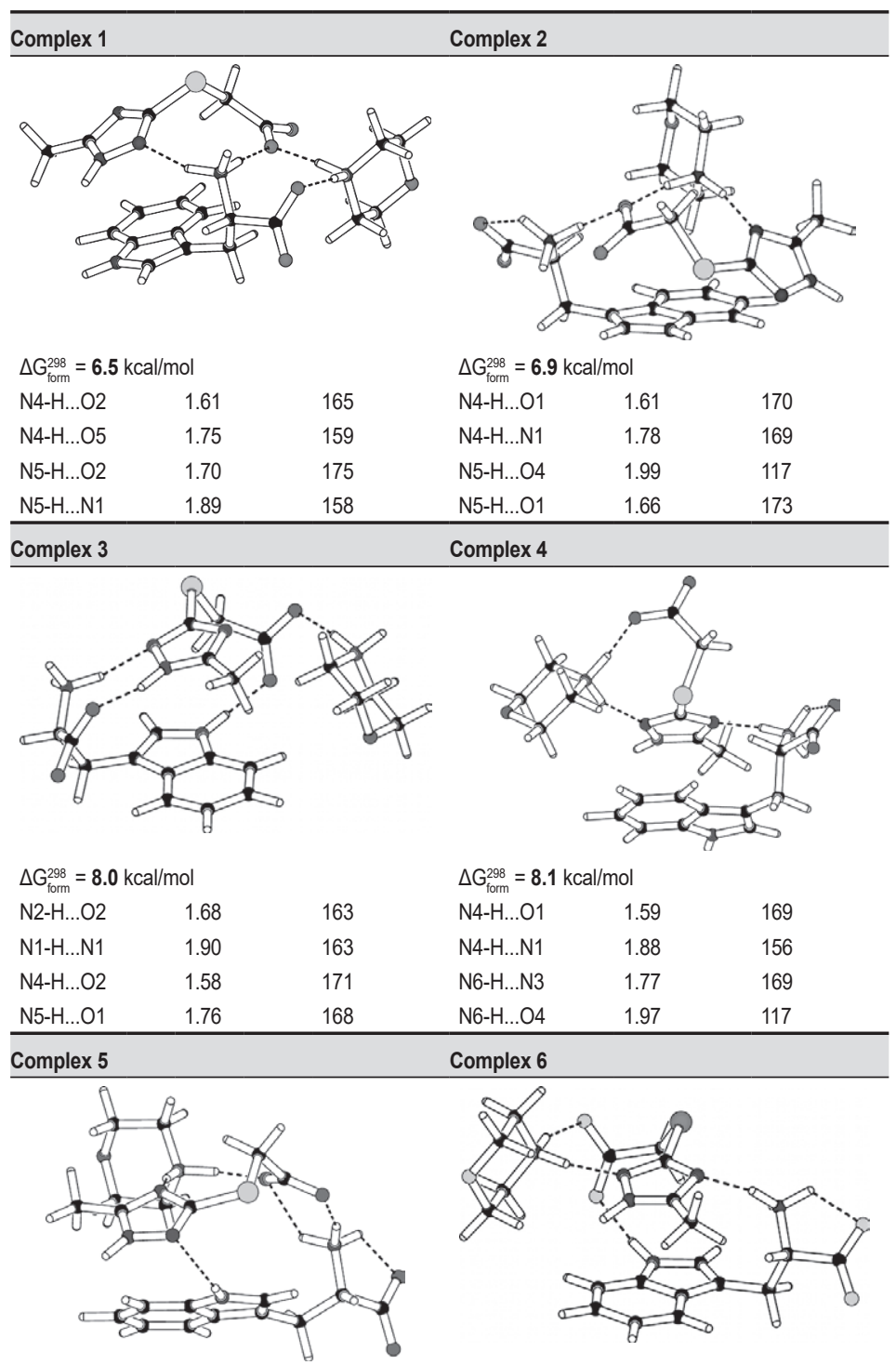

$\Delta \mathrm{G}_{\mathrm{form}}^{298}=8.1 \mathrm{kcal} / \mathrm{mol}$

$\begin{array}{lll}\text { N4-H...O1 } & 1.59 & 169 \\ \text { N4-H...N1 } & 1.88 & 156 \\ \text { N6-H...N3 } & 1.77 & 169 \\ \text { N6-H...O4 } & 1.97 & 117\end{array}$

Complex 6

$\Delta \mathrm{G}_{\mathrm{fom}}^{298}=8.6 \mathrm{kcal} / \mathrm{mol}$

$\begin{array}{lll}\text { N4-H...O1 } & 1.55 & 173 \\ \text { N4-H...N1 } & 1.92 & 165 \\ \text { N5-H...O4 } & 1.92 & 120 \\ \text { N5-H...O1 } & 2.39 & 113 \\ \text { N5-H...O2 } & 1.72 & 163\end{array}$

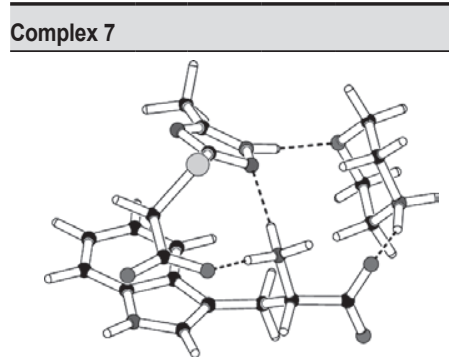

$\Delta \mathrm{G}_{\mathrm{fom}}^{298}=9.4 \mathrm{kcal} / \mathrm{mol}$

$\mathrm{N} 2-\mathrm{H}$...O3 $\quad 1.86$

N4-H...O5 $\quad 1.64$

N6-H...O2 $\quad 1.60$

N6-H...N3 $\quad 1.99$

162

156

174

169
$\Delta \mathrm{G}_{\text {form }}^{298}=9.3 \mathrm{kcal} / \mathrm{mol}$

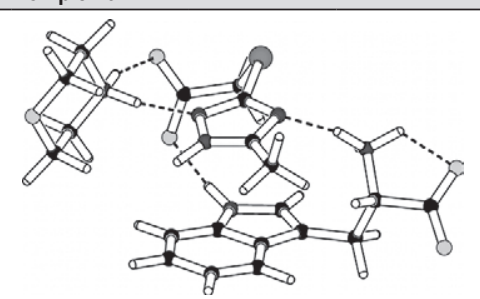

$\mathrm{N} 4-\mathrm{H} \quad \mathrm{O} 2$

N4-H...N1 $\quad 1.86$

N5-H...O1 $\quad 1.80$

N6-H...N3 $\quad 1.82$

N6-H...O5

1.92

Complex 8

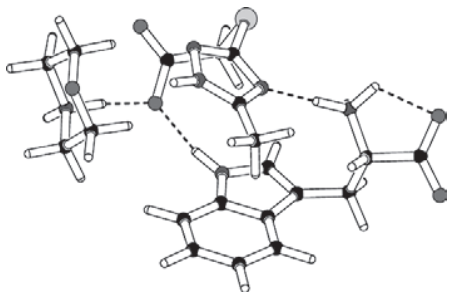

$\Delta \mathrm{G}_{\text {form }}^{298}=9.4 \mathrm{kcal} / \mathrm{mol}$

$\mathrm{N} 4-\mathrm{H} . . .01$

N5-H...O1 $\quad 1.86$

N6-H...N1 $\quad 1.76$

N6-H...O5 2.02
69

156 


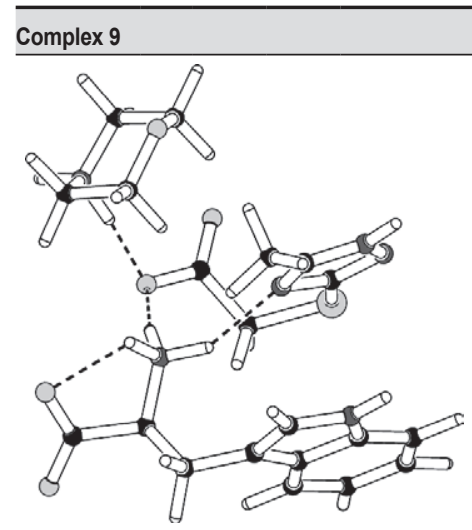

$\Delta \mathrm{G}_{\mathrm{form}}^{298}=9.5 \mathrm{kcal} / \mathrm{mol}$

$\mathrm{N} 4-\mathrm{H}-\mathrm{O} 1$

N5-H...O5 $\quad 2.06$

N5-H...O1 1.65

N5-H...N1 2.02

Complex 10

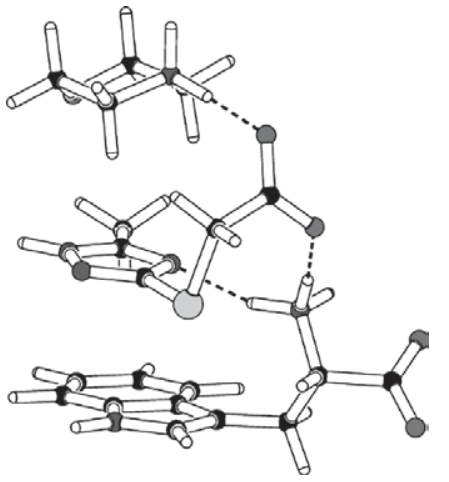

$\Delta \mathrm{G}_{\text {form }}^{298}=9.8 \mathrm{kcal} / \mathrm{mol}$

$\mathrm{N} 4-\mathrm{H} . . .01 \quad 1.60$

N5-H...O2 $\quad 1.70$

$\mathrm{N} 5-\mathrm{H} . . . \mathrm{O} 4 \quad 2.18$

N5-H...N1 $\quad 1.94$

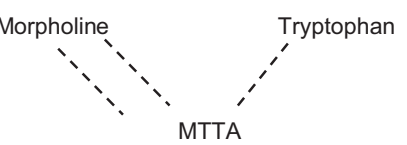

Complex 2

Morpholine

Complex 1<smiles>[Y10]CCCCCCCC</smiles>

Complex 3

Morpholine

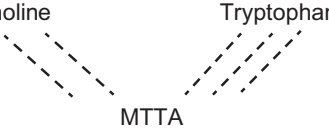

Complex 5

Morpholine

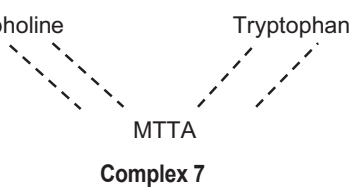

Morpholine

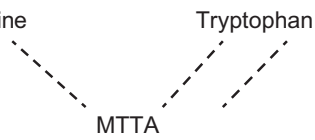

Complex 9

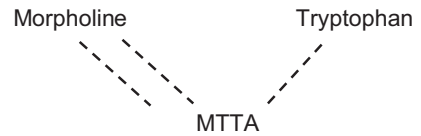

Complex 4

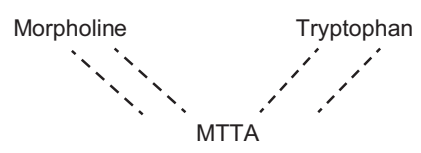

Complex 6
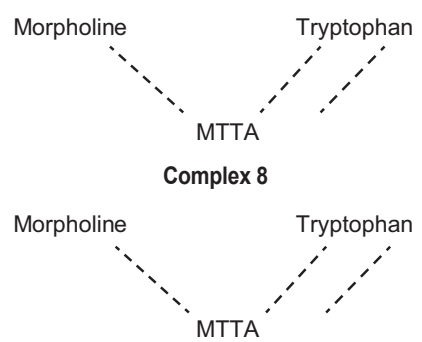

Complex 10
Fig. 4. Different types of binding in the studied three-component complexes.

\section{Conclusions}

The results of the quantum-chemical study of the system consisting of three components (L-tryptophan, MTTA and morpholine) showed that the most thermodynamically stable three-component complexes have a positive energy of formation in infinitely dilute solutions.

Despite the possibility of the formation of intermolecular hydrogen bonds between the components, some of which are charge-assisted, the L-tryptophan, MTTA and morpholine system is a mixture of substances, which makes it possible to use them in a single dosage form.

\section{References}

[1] Gbiadoni, L., Donald A. E., Cropley, M., Mullen, M. J., Oakley, G. Taylor, M., et al. (2000) Mental stress induces transient endothelia dysfunction in humans. Circulation, 102, 2473-2478.

[2] Kucherenko, L. I., Borsuk, S. O., Bielenichev I. F., et al. (patentee) (2016) Patent 112513, Ukraine, МПК (2016), A61K 31/405 (2006.01) A61K 31/41 (2006.01) A61 P 25/00 A61P 25/28 (2006.01). Kombinovanyi likarskyi zasib anksiolitychnoi, stres-protektyvnoi, nootropnoi i antyoksydantnoi dii [Combination drug of anxiolytic, stress-protective, nootropic and antioxidant action]. Biulenen, 12. [in Ukrainian].

[3] Mazur, I. A., Voloshin, N. A., Chekman, I. S., Zimenkovskij, B. S., \& Stec, V. P. (2005) Tiotriazolin [Thiotriazoline]. Zaporozhye, Lvov: Nautilus. [in Russian].

[4] Zubatiuk, R. I., Kucherenko, L. I., Mazur, I. A., Khromyleva, O. V., \& Shyshkin, O. V. (2014) Teoreticheskoe issledovanie stroeniya kompleksov izoniazida s tiotriazolinom [Theoretical study of the structure of complexes with isoniazid Thiotriazoline]. Khimiya geterociklicheskikh soedinenij, 3, 476-482. [in Russian].

[5] Trott, O., \& Olson, A. J. (2010) Software news and update AutoDock Vina: Improving the speed and accuracy of docking with a new scoring function, efficient optimization, and multithreading. J. Comput. Chem., 31, 455-461. doi: 10.1002/jcc.21334.

[6] Stewart, J. J. P. MOPAC2012, Colorado Springs, CO: Stewart Computational Chemistry, 2012.

[7] Grimme, S., Ehrlich, S., \& Goerigk, L. (2011) Effect of the damping function in dispersion corrected density functional theory. J. Comput. Chem, 32, 1456-1465. doi: 10.1002/jcc.21759.

[8] Kruse, H., \& Grimme, S. (2012) A geometrical correction for the interand intra-molecular basis set superposition error in Hartree-Fock and density functional theory calculations for large systems. J. Chem. Phys, 136, 154101. doi: 10.1063/1.3700154.

[9] Neese, F. (2012) The ORCA program system. Rev. Comput. Mol. Sci, 2, 73-78.

[10] Shishkina, S. V., Zubatyuk, R. I., Kucherenko, L. I., Mazur, I. A., \& Shishkin, O. V. (2009) Two polymorphs of morpholin-4-ium 2-(5-methyl1H-1,2,4-triazol-3-ylsulfanyl)acetate. Acta Crystallographica Section, 65(Pt 1):024-6. doi: 10.1107/S0108270108042042.

\section{Information about authors:}

Kucherenko L. I., Dr.hab., Professor, Head of the Department of Pharmaceutical Chemistry, Zaporizhzhia State Medical University, Vice-President of SPA “Farmatron”, Zaporizhzhia, Ukraine.

Mazur I. A., Dr.hab., Professor, the Department of Pharmaceutical Chemistry, Zaporizhzhia State Medical University, President of SPA "Farmatron", Zaporizhzhia, Ukraine.

Borsuk S. A., Assistant professor, the Department of

Pharmaceutical Chemistry, Zaporizhzhia State Medical University, Ukraine.

Khromylova O. V., Ph.D., Senior Lecturer, the Department of Pharmaceutical Chemistry, Zaporizhzhia State Medical University, Ukraine.

Shishkina S. V., Ph.D., analyst at SPA “Farmatron”, Zaporizhzhia, Ukraine.

\section{Відомості про авторів:}

Кучеренко ^. І., А-р фарм. наук, професор, зав. каф. фармацевтичної хімії, Запорізький державний медичний університет, віце-президент НВО “Фарматрон", м. Запоріжжя, Україна.

Мазур І. А., А-р фарм. наук, професор каф. фармацевтичної хімії, Запорізький Аержавний меАичний університет, презилент HBO «Фарматрон", м. Запоріжжя, Україна.

Борсук С. О., викладач-стажист каф. фармацевтичної хімії, Запорізький державний медичний університет, Україна. Хромильова О. В., канА. фарм. наук, старший викладач каф. фармацевтичної хімії, Запорізький Аержавний медичний університет, Україна.

Шишкіна С. В., канА. хім. наук, аналітик НВО “Фарматрон”, м. Запоріжжя, Україна.

\section{Сведения об авторах:}

Кучеренко ^. И., А-р фарм. наук, профессор,

зав. каф. фармацевтической химии, Запорожский государственный медицинский университет, вице-президент НПО "Фарматрон", г. Запорожье, Украина. 
Мазур И. А., А-р фарм. наук, профессор,

каф. фармацевтической химии, Запорожский государственный

меАицинский университет, президент НПО “Фарматрон”,

г. Запорожье, Украина.

Борсук С. А., преподаватель-стажер каф. фармацевтической

химии, Запорожский госуАарственный меАицинский

университет, Украина.

Хромылёва О. В., канА. фарм. наук, старший преподаватель

каф. фармацевтической химии, Запорожский государственный медицинский университет, Украина.

Шишкина С. В., канА. хим. наук, аналитик НПО "Фарматрон",

г. Запорожье, Украина.

Conflicts of interest: authors have no conflict of interest to declare. Конфлікт інтересів: віАсутній.

Надійшла Ао редакції / Received: 15.06.2017

Після Аоопрацювання / Revised: 18.08.2017

Прийнято Ао Аруку / Accepted: 04.09.2017 